J. Clin. Chem. Clin. Biochem.

Vol. 23, 1985, pp. $177-181$

\title{
Tamm-Horsfall Protein in Balkan Endemic Nephropathy
}

\author{
By Dubravka Čvorišćec
}

Institute for Clinical Laboratory Diagnostics, Clinical Hospital Centre Zagreb

Ana Stavljenić

Institute for Clinical Laboratory Diagnostics, Clinical Hospital Centre Zagreb, and

\section{Radonić}

Department of Medicine, Medical Faculty, University of Zagreb, Clinical Hospital Centre Zagreb

(Received August 28, 1984/January 31, 1985)

Summary: It is suggested that Tamm-Horsfall protein, a specific renal glycoprotein, may be involved in the pathogenesis of some renal diseases. In cadmium nephropathy and Fanconi syndrome (primary tubular diseases of the kidney) an increased excretion rate of Tamm-Horsfall protein has been observed.

Balkan endemic nephropathy is a chronic tubulointerstitial disease of unknown etiology, most probably a primary disease of the kidney tubules with secondary reaction of the interstitial tissue. Investigation of TammHorsfall proteinuria in Balkan endemic nephropathy has shown that subjects living in the area where this condition is prevalent have a significantly higher Tamm-Horsfall protein/creatinine ratio than those living in the control area where the condition has not been observed.

Differences in this ratio among diseased, suspect and subjects "at risk" were not observed, despite differences in their glomerular filtration rates. But excretion of Tamm-Horsfall protein per litre of glomerular filtrate was significantly different among diseased, suspect and subjects "at risk" and significantly higher compared to control subjects.

A relatively significant correlation was obtained between Tamm-Horsfall protein excretion rate and glomerular filtration rate as measured by creatinine clearance in both control and subjects living in the area of Balkan endemic nephropathy.

Determination of Tamm-Horsfall protein in urine together with determination of proteinuria by electrophoresis on cellulose acetate membranes. as a screening procedure, and by SDS-electrophoresis in polyacrylamide gel may be useful labboratory tests in detecting this nephropathy.

\section{Tamm-Horsfall-Protein bei endemischer Balkan-Nephropathie}

Zusammenfassüng: Es wird angenommen, daß Tamm-Horsfall-Protein - ein spezifisches renales Glykoprotein - an der Pathogenese gewisser renaler Krankheiten beteiligt sein könnte. Bei der Cadmiumnephropathie und dem Fanconi-Syndrom - primären tubulären Nierenkrankheiten - wurde eine erhöhte Ausscheidungsrate des Tamm-Horsfall-Proteins beobachtet.

Die endemische Balkan-Nephropathie ist eine chronische tubulointerstitielle Krankheit unbekannter Ätiologie, höchst wahrscheinlich eine primäre Krankheit der Nierentubuli mit sekundärer Reaktion des interstitiellen Gewebes. 
Die Untersuchung der Tamm-Horsfall-Proteinurie bei endemischer Balkan-Nephropathie hat gezeigt, daß die in dem Endemie-Gebiet lebenden Personen eine erheblich höhere Tamm-Horsfall-Protein/KreatininAusscheidungsrate aufweisen im Vergleich zu denjenigen, die in einem Kontrollgebiet leben, wo die Erkrankung bisher nicht beobachtet wurde. Ein Unterschied zwischen den Erkrankten, Verdächtigen und den „Risikopersonen“ wurde ungeachtet ihrer verschiedenen glomerulären Filtrationsraten nicht beobachtet. Auf der anderen Seite unterschied sich die Ausscheidungsrate des Tamm-Horsfall-Proteins pro 1 glomerulären Filtrates erheblich zwischen den Erkrankten, Verdächtigen und „Risikopersonen“ und 'war, verglichen mit Kontrollen, signifikant höher.

Eine signifikante Korrelation wurde zwischen der Tamm-Horsfall-Protein-Ausscheidungsrate und der glomerulären Filtration, gemessen als Kreatininclearance, bei den Kontrollen und den Bewohnern des EndemièGebiets gewonnen.

Die Bestimmung des Tamm-Horsfall-Proteins im Harn zusammen mit der Bestimmung von Proteinurie durch Elektrophorese auf Celluloseacetatmembranen als Screeningverfahren und mit SDS-Elektrophorese in Polyacrylamidgel, können nützliche Labortests zum Nachweis der endemischen Balkan-Nephropathie sein.

\section{Introduction}

Tamm-Horsfall protein is a renal epithelial glycoprotein of high relative molecular mass $\left(7 \times 10^{6}\right.$ daltons) derived from the tubular cells of the ascending thick limb of Henle's loop (1-3). It is normally present in human urine and represents a major component of urinary casts. Although the physiological function of Tamm-Horsfall protein is not unequivocally known, its specific localization and some unusual chemical and physical properties suggest that it might be involved in the regulation of membrane transport of chloride ions and associated cations and may be involved in the pathogenesis of some renal diseases (3).

Urinary excretion of Tamm-Horsfall protein appears to be fairly constant $(4,5)$. No significantly diurnal variation in the excretion of Tamm-Horsfall protein has been found (6).

In most patients with chronic renal failure the excretion of Tamm-Horsfall protein was decreased in proportion to the decrease in glomerular filtration rate $(4,5)$. In patients with cadmium nephropathy and Fanconi syndrome, normal excretion of TammHorsfall protein was observed in spite of decreased creatinine clearance. This finding indicates an increased excretion rate of Tamm-Horsfall protein relative to the glomerular filtration rate (4). Increased excretion of Tamm-Horsfall protein was observed in some patients with nephrotic syndrome although a direct correlation with the excretion of serum proteins was not found (5). This increase might be related to the increased delivery of sodium chloride to the distal tubule, and only secondary to the nephrotic syndrome. Increased excretion of Tamm-Horsfall protein in acute renal tubular injury produced by potassium dichromate (7) may be due either to an increased production of Tamm-Horsfall protein by the epithelial cells or to an increased release of Tamm-Horsfall protein from the membrane of the same cells. In acute phase of renal allograft rejection, high excretion of Tamm-Horsfall protein was observed prior to the clinical diagnosis of the allograft rejection (8). This observation suggests that measurement of TammHorsfall protein in urine may be helpful in the early detection of renal tubular damage.

Although it seems that the major pathogenetic contribution of intratubular "Tamm-Horsfall protein is tubular obstruction by urinary casts, disruption of tubular integrity and urinary extravasation may lead to an additional pathogenetic role for this protein (3). Osmotic removal of water from urine may lead to precipitation of Tamm-Horsfall protein. Using antisera to Tamm-Horsfall protein extratubular deposits of Tamm-Horsfall protein were demonstrated in human renal diseases, frequently in medullary cystic disease, chronic pyelonephritis, obstructive uropathy with vesicouretheral reflux and in other forms of the tubulointerstitial nephritis $(9-11)$.

Balkan endemic nephropathy is a chronic tubulointerstitial disease of unknown etiology (12). Proteinuria is one of the early signs of this condition and its characteristics have been intensively investigated by various electrophoretic procedures for proteins (electrophoresis on filter paper or agarose, electrophoresis in polyacrylamide gel, electrophoresis on cellulose acetate membranes, immunoelectrophoresis), as well as by qualitative and quantitative determination of $\beta_{2}$-microglobulin in urine (13-18). 
The aim of this work was to examine the excretion of Tamm-Horsfall protein in subjects living in the endemic area and control area. In the same subjects, the type of proteinuria was determined by electrophoresis on cellulose acetate membranes and SDSelectrophoresis in polyacrylamide gel.

\section{Materials and Methods}

The Tamm-Horsfall protein excretion value and grade and type of proteinuria were measured in urine samples of 94 subjects of both sexes ages 18 to 78 years living in the area of Balkan endemic nephropathy and in 32 subjects from the control area where the condition has not been observed. Subjects from the endemic area were divided into three groups according to the criteria: diseased, suspect and group "at risk" (19). Diseased subjects were considered to be those who had significant proteinuria (sulphosalicylic acid test positive and/or low molecular weight test positive; the low molecular weight test is a simple immunodiffusion test for the determination of $\beta_{2}$-microglobulin in native urine), anaemia (haemoglobin below $120 \mathrm{~g} / \mathrm{l}$ in males and below $113 \mathrm{~g} / \mathrm{l}$ in females) and blood creatinine above $132.6 \mu \mathrm{mol} / \mathrm{l}$, or proteinuria, anaemia and positive family medical history of Balkan endemic nephropathy, or all the four elements together. Suspect subjects were considered to be those who had both proteinuria and anaemia, or proteinuria and a positive family medical history of the complaint. Subjects "at risk" were considered to be those belonging to families with the disease, but lacking clinical symptoms of kidney disease and without pathological laboratory findings in their own history.

Overnight urine samples were collected in plastic bottles in the course of $8-12$ hours.

Tamm-Horsfall protein concentration in total urine samples was measured by electrophoresis in $1 \%$ agarose gel containing antiserum against Tamm-Horsfall protein $\left(3.0 \mu \mathrm{l} / \mathrm{cm}^{2}\right)(20)$. The volume of antigen applied was $5 \mu \mathrm{l}$. Tamm-Horsfall protein was isolated from a pool of human urine by a modified method of Tamm \& Horsfall (21). Crude precipitate was further purified by Sephadex G-200 gel chromatography in $6 \mathrm{~mol} / 1 \mathrm{lurea}, \mathrm{pH} 8.5$. Antiserum against Tamm-Horsfall protein was prepared by immunization of rabbits with isolated antigen in complete Freund adjuvant. Before determination of Tamm-Horsfall protein $5 \mathrm{ml}$ of total urine sample was dialysed overnight at $4^{\circ} \mathrm{C}$, the volume was reduced to $2.5 \mathrm{ml}$ and $2.0 \mathrm{ml}$ of concentrate was added to $0.1 \mathrm{ml}$ of sodium dodecyl sulphate $(63 \mathrm{~g} / 1)$ followed by incubation at $37^{\circ} \mathrm{C}$ for 1 hour.

Tab. 1. Values of serum creatinine and creatinine clearance in subjects from the area of Balkan endemic nephropathy and in the control area.

\begin{tabular}{|c|c|c|c|c|}
\hline \multirow{2}{*}{ • } & \multicolumn{2}{|c|}{$\begin{array}{l}\text { Serum creatinine } \\
(\mu \mathrm{mol} / \mathrm{l})\end{array}$} & \multicolumn{2}{|c|}{$\begin{array}{l}\text { Creatinine clearance } \\
(\mathrm{ml} / \mathrm{min})\end{array}$} \\
\hline & Range & $\overline{\mathbf{x}}$ & Range & $\bar{x}$ \\
\hline $\begin{array}{l}\text { Diseased } \\
n=25\end{array}$ & $123-752$ & 388 & $2.95-55.8$ & 22.3 \\
\hline $\begin{array}{l}\text { Suspect } \\
n=33\end{array}$ & $50-1053$ & 156 & $3.6-193.2$ & 60.9 \\
\hline $\begin{array}{l}\text { "At riskk" } \\
n=36\end{array}$ & $42-111$ & 79 & $40.4-132.9$ & 89.5 \\
\hline $\begin{array}{l}\text { Control } \\
n=32\end{array}$ & $52-120$ & 79 & $50.2-160.7$ & 104.7 \\
\hline
\end{tabular}

Tamm-Horsfall protein purified from normal urine was used as standard $(2.5 \mathrm{mg} / \mathrm{ml})$. Working standard solutions were obtained by dilution with a $3 \mathrm{~g} / \mathrm{l}$ solution of sodium dodecyl sulphate. Total protein concentration in urine was determined by the biuret method (22). Electrophoresis of native urine was performed on cellulose acetate membranes in $0.4 \mathrm{~mol} / 1$ trisglycine buffer, $\mathrm{pH} 9.5$ at a voltage of $240 \mathrm{~V}$ for 3 hours and $30 \mathrm{~min}$. For. the identification of protein we used an electrophoretogram of protein standards. The type of proteinuria was determined according to the criteria described in our previous work (18). SDS-electrophoresis of urine proteins was performed in $7.5 \%$ polyacrylamide gel in tris-glycine buffer containing $0.1 \%$ sodium dodecyl sulphate $\mathrm{pH} 8.3$ at a voltage of $450 \mathrm{~V}$, and very intensive cooling (water, precooled to $4-10^{\circ} \mathrm{C}$ ) for $40 \mathrm{~min}$. Previously, urine samples were dialysed against distilled water, concentrated to a protein concentration of about $10 \mathrm{~g} / \mathrm{l}$, then $20 \mu \mathrm{l}$ of concentrate were incubated with $2 \mu \mathrm{l}$ of sodium dodecyl sulphate and one crystal of sucrose for 1 hour at $37^{\circ} \mathrm{C}$. Identification of certain protein fractions was made by comparison with an electrophoretogram of protein standards, aided by the inclusion of plasma albumin as an internal marker in each investigated urine sample $(23,24)$.

Serum and urine creatinine concentrations were measured by an automated kinetic Jaffe method on the Abbott VP (25).

\section{Results}

Table 1 presents values of serum creatinine and endogenous creatinine clearance in subjects living in the endemic area and in control subjects. In the group of diseased subjects, values of creatinine clearance were within the range of 3.0 to $55.8 \mathrm{ml} / \mathrm{min}$ in suspect subjects within a wide range of 3.6 to $193.2 \mathrm{ml} / \mathrm{min}$, and in subjects "at risk" within the range of 40.4 to $132.9 \mathrm{ml} / \mathrm{min}$. In control subjects only one had a slightly reduced glomerular filtration rate, whereas the others had normal glomerular filtration rates.

Results obtained by measuring the excretion of Tamm-Horsfall protein in subjects from the endemic and control areas are presented in table 2. Excretion of Tamm-Horsfall protein is expressed as milligrams

Tab. 2. Excretion rate of Tamm-Horsfall protein in subjects from the area of Balkan endemic nephropathy and in the control area.

\begin{tabular}{|c|c|c|c|c|}
\hline & \multicolumn{4}{|c|}{ Tamm-Horsfall protein } \\
\hline & \multicolumn{2}{|c|}{ (mg/g creatinine) } & \multicolumn{2}{|c|}{$\begin{array}{l}\text { (mg/l glomerular } \\
\text { filtrate) }\end{array}$} \\
\hline & Range & $\overline{\mathrm{x}}$ & Range & $\overline{\mathrm{x}}$ \\
\hline $\begin{array}{l}\text { Diseased } \\
n=25\end{array}$ & $9.6-96.5$ & 28.6 & $0.14-2.51$ & 1.13 \\
\hline $\begin{array}{l}\text { Suspect } \\
n=33\end{array}$ & $4.7-56.3$ & 28.2 & $0.10-1.39$ & 0.41 \\
\hline $\begin{array}{l}\text { "At risk" } \\
\mathrm{n}=36\end{array}$ & $9.1-64.4$ & 28.2 & $0.10-0.60$ & 0.25 \\
\hline $\begin{array}{l}\text { Control } \\
\mathrm{n}=32 \\
\end{array}$ & $2.0-45.8$ & 19.6 & $0.10-0.32$ & 0.18 \\
\hline
\end{tabular}


per gram of creatinine, and as milligrams per liter of glomerular filtrate. The Tamm-Horsfall protein/ creatinine ratio in diseased, suspect and subjects "at risk" was significantly higher than in control subjects $(p<0.05)$. However, no difference was observed in the Tamm-Horsfall protein/creatinine ratio between diseased, suspect and subjects "at risk". Due to the different glomerular filtration rates in diseased, suspect and subjects "at risk", the excretion of TammHorsfall protein per liter of glomerular filtrate was significantly different between diseased and suspect subjects ( $<<0.05)$, between suspect and subjects "at risk" ( $p<0.05)$, and between diseased and subjects "at risk" ( $p<0.05$ ), as well as among diseased, suspect and subjects "at risk" and control subjects $(\mathrm{p}<0.05)$.

In diseased and suspect subjects a relatively high negative correlation between excretion rate of TammHorsfall protein and glomerular filtration rate was observed $(r=0.61$ in diseased subjects and $r=0.50$ in suspect suibjects). Subjects "at risk" also showed a correlation but this was not statistically significant.

A statistically significant negative correlation between the excretion rate of Tamm-Horsfall protein and the glomerular filtration rate was also found in control subjects $(r=0.57)$.

The presence of certain types of proteinuria determined by electrophoresis of native urine on cellulose acetate membranes and by SDS-electrophoresis in polyacrylamide gel in subjects from endemic and control area are presented in table 3.

\section{Discussion}

Numerous investigations of Balkan endemic nephropathy have shown that tubular epithelial cells are markedly damaged while glomeruli are unchanged or slightly changed in the early phase of the disease. Thus, the tests for evaluation of tubular function are reduced, whereas those for evaluation of glomerular filtration rate are normal. In later stages of the disease, the glomerular filtration rate also becomes reduced (12).

As mentioned above, individual groups of subjects from the endemic area show notable differences of endogenous creatinine clearance, i.e. glomerular filtration rate.

Proteinuria is one of the early signs of Balkan endemic nephropathy. Based on the results obtained in this work one can conclude that the degree of proteinuria was relatively low in subjects from the endemic area. Determination of the type of proteinuria by electrophoresis of native urine on cellulose acetate membranes has shown that urine from subjects suffering from the disease characteristically contains a clearly defined fraction of $\beta_{2}$-microglobulin, a diminished or normal albumin fraction, and a transferrin fraction slightly pronounced or absent. By this very simple procedure for determining the type of proteinuria, which is particularly suited to epidemiological work, it has been observed that almost $40 \%$ of subjects from the endemic area have tubular type proteinuria.

Tab. 3. Distribution of the types of proteinuria in subjects from the area of Balkan endemic nephropathy and from the control area determined by electrophoresis on cellulose acetate membranes and by SDS-electrophoresis in polyacrylamide gel. $\mathrm{Ph}=$ physiological proteinuria. $\mathrm{T}=$ tubular proteinuria. $\mathrm{G}_{\mathrm{s}}=$ selective glomerular proteinuria. $\mathrm{M}=$ mixed proteinuria.

\begin{tabular}{|c|c|c|c|c|c|c|c|c|}
\hline & \multicolumn{8}{|c|}{ Types of proteinuria } \\
\hline & \multicolumn{4}{|c|}{$\begin{array}{l}\text { Electrophoresis on cellulose } \\
\text { acetate membranes }\end{array}$} & \multicolumn{4}{|c|}{$\begin{array}{l}\text { SDS-electrophoresis in } \\
\text { polyacrylamide gel }\end{array}$} \\
\hline & $\mathrm{Ph}$ & $\mathrm{T}$ & $\mathrm{G}_{\mathrm{s}}$ & $\mathbf{M}$ & $\mathrm{Ph}$ & $\mathrm{T}$ & $\mathrm{G}_{\mathrm{s}}$ & $\mathbf{M}$ \\
\hline $\begin{array}{l}\text { Diseased } \\
\mathrm{n}=25\end{array}$ & 3 & 19 & 3 & - & 3 & 10 & 3 & 9 \\
\hline $\begin{array}{l}\text { Suspect } \\
n=33\end{array}$ & 16 & 8 & 9 & - & 16 & 7 & 1 & \\
\hline $\begin{array}{l}\text { "At risk" } \\
\mathrm{n}=32\end{array}$ & 34 & - & 2 & - & 34 & - & 2 & - \\
\hline $\begin{array}{l}\text { Control } \\
n=32\end{array}$ & 30 & - & 2 &.- & 30 & - & 2 & - \\
\hline
\end{tabular}


Evaluation of electrophoretograms obtained by SDSelectrophoresis in polyacrylamide gel has shown that subjects suffering from the disease excrete an increased quantity of plasma proteins of relative molecular mass smaller than albumin. Along with $\beta_{2-}$ microglobulin there are also plasma proteins whose common characteristic is a molecular mass smaller than albumin. It is obvious that in a later stage of the disease, when glomeruli are also affected, excretion of plasma proteins with relative molecular mass greater than albumin takes place.

These results support those authors who consider Balkan endemic nephropathy to be a primary tubular disease of the kidney. Evaluation of the excretion of Tamm-Horsfall protein, expressed as milligrams per gram of creatinine, showed that in the individual groups of subjects from the endemic area there were no marked differences in the excretion of this protein. However, compared with control subjects this value was significantly higher $(\mathrm{p}<0.05)$. But excretion of Tamm-Horsfall protein, expressed as milligrams per liter of glomerular filtrate, was significantly different among diseased, suspect and subjects "at risk". This finding indicates an increased excretion of TammHorsfall protein per functional nephron unit.

Relatively high negative correlation was observed between the excretion rate of Tamm-Horsfall protein

\section{References}

1. Tamm, I. \& Horsfall, F. L. Jr. (1952) J. Exp. Med. 95, $71-97$.

2. Hoyer, J. R., Sisson, S. \& Vernier, R. L. (1978) Fed. Proc. $37,837$.

3. Hoyer, J. R. \& Seiler, M.W. (1979) Kidney Inț. 16, $279-289$.

4. Grant, A. M.S., Baker, L. R. I. \& Neuberger, A. (1973) Clin. Sci. 44, 377-384.

5. McKenzie, J. K., Patel, R. \& McQueen, E. G. (1964) Aust. Ann. Med. 13, 32-39.

6. Mazzuchi, N., Pecarovich, R., Ross, N., Rodriquez, I. \& Sangiunetti, C. M. (1974) J. Lab. Clin. Med. 84, 771-776.

7. Schwartz, R.H., Lewis, R. A. \& Schenk, E. A. (1972) Lab. Invest. 27, 214-217.

8. Schwartz, R.H., van Ess, J. D., May, A. G. \& Schenk, E. A. (1973) Transplantation $16,83-87$.

9. Zager, R.A., Cotran, R.S. \& Hoyer, J.R. (1978) Lab. Invest. $38,52-5 \overline{7}$

10. Resnick, J.S., Sisson, S. \& Vernier, R. L. (1978) Lab. Invest. $38,550-555$.

11. Solez, K. \& Heptinstall, R.H. (1978) J. Urol. 119, 180-183.

12. Radonić, M., Radošević, Z. \& Županić, V. (1966) In: The kidney (Mostofi, F. K. \& Smith, D. E., eds.) Baltimore, pp. $503-522$

13. Bruckner, I., Stoica, Gh. \& Serban, M. (1967) In: The Balkan Nephropathy, Ciba Foundation, Study Group No. 30, Londón, pp. 84-99.

14. Hall, P. W., Gaon, J., Griggs, R. C., Piscator, M. \& Popović, N. (1967) In: The Balkan Nephropathy, Ciba Foundation Study Group No. 30, London, pp. 72-83. and the glomerular filtration rate in diseased, suspect and control area $(r=0.61 ; 0.50$ and 0.57 respectively).

Grant et al. (4) found an increased excretion rate of Tamm-Horsfall protein per functional nephron unit in cadmium nephropathy and Fanconi syndrome, probably due to an increased synthesis of TammHorsfall protein in epithelial cells of the ascending thick limb of Henle's loop. As pathological changes in Balkan endemic nephropathy seem to be very similar to those in cadmium nephropathy and perhaps also to those in Fanconi syndrome, it is assumed that the increased excretion rate of TammHorsfall protein in Balkan endemic nephropathy is due to an increased synthesis of Tamm-Horsfall protein in the damaged cells of the ascending thick limb of Henle's loop. The question is whether the normal physiological function of the ascending thick limb of Henle's loop is therefore disturbed.

The finding of an elevated excretion rate of TammHorsfall protein in subjects "at risk" suggests that measurement of urinary Tamm-Horsfall protein together with the determination of the type of proteinuria in subjects living in the endemic area could be useful in the early detection of renal tubular damage in Balkan endemic nephropathy.

15. Hrabar, A., Radošević, Z., Radonić, M., Keler-Bačoka, M., Mihelčić, N., Čeović, S., Borčić, B., Stefanović, S. Čvoriščec, D. \& Hall, P. W. (1971-1974) In: Report on investigation of endemic nephropathy, Phase I, Public Law 83,480 .

16. Hall, P. W. \& Vasiljević, M. (1973) J. Lab. Clin. Med. 81, 897-904.

17. Radonić, M., Mikuličić, V., Čeović, S., Aleraj, B., Hrabar, A., Radošević, Z. \& Čvoriščce, D. (1979) In: Proceedings of the 4th Symposium on Endemic (Balkan) Nephropathy, Niš, pp. $141-145$

18. Čvorišćec, D., Radonić, M., Čeović, S. \& Aleraj, B. (1983) J. Clin. Chem. Chim. Biochem. 21, 569-571.

19. Hrabar, A., Aleraj, B., Borčić, B. \& Čeović, S. (1979) In: Proceedings of the 4th Symposium on Endemic (Balkan) Nephropathy, Niš, pp. 233-239.

20. Laurell, C. B. (1972) Scand. J. Clin. Lab. Invest. 29, Suppl. 124: 21.

21. Tamm, I. \& Horsfall, F. L. Jr. (1950) Proc. Soc. Exp. Biol. Med. 74, 108-114.

22. Savory, J., Pu, P. H. \& Sunderman, F. M. (1968) Clin. Chem. 14, 1160-1170.

23. Balant, L., Mulli, J. C. \& Fabre, J. (1974) Clin. Chim. Acta $54,27-37$.

24. Boesken, H. (1979) In: Diagnostic significance of enzymes and proteins in urine (Dubach, U.C. \& Schmidt, U., eds.) Bern, pp. 235-248.

Dubravka Cvorišćec, Ph. D.

Institute for Clinical Laboratory Diagnostics

Clinical Hospital Centre Zagreb

Kišpatićeva 12

YU-41000 Zagreb 
